\title{
Developing Inquiry-Based Learning Materials Through Integrated Lesson Study with 4-D Model to Enhance Junior High School Students' Critical Thinking Skill
}

\author{
Agus Ramdani* \\ Study Program of Science Education \\ Mataram University \\ Mataram, Indonesia \\ *aramdani07@unram.ac.id
}

\begin{abstract}
Critical thinking is an important skill that needs to be developed for the future of the students. However, this has not been facilitated properly in the learning process of science at junior high school. This study aims to develop inquiry-based science learning materials that are valid, practical, and effective to improve students' critical thinking skills. This $R$ and $D$ study adapted the 4D model (define, design, develop, disseminate) which is integrated with lesson study activities. The trial subjects in this study were students of class VIII SMPN in the city of Mataram. The development of learning devices uses lesson study activities (plan, do, see) that involve SMPN science teachers in the city of Mataram. Product feasibility testing was carried out by experts using the validation instrument prepared by the researcher. Testing the practicality of the learning process uses the implementation observation sheet, teacher response questionnaire, student response questionnaire, and observation sheet of student's critical thinking abilities. The results of the data analysis show that learning materials were in the category of high validity, high practicality and effective for improving students' critical thinking skills. In conclusion, the learning materials of inquiry-based learning model developed through lesson study activities had proved to improve students' critical thinking skills.
\end{abstract}

Keywords: 4-D model, lesson study, inquiry-based learning, critical thinking skill

\section{INTRODUCTION}

The challenge faced by the world of education, both present and future, is to prepare students who possess higher-level thinking skills and ability to collaborate with others in developing and applying science and technology [1]. The results of the PISA study, which is conducted every 3 years, show that the scientific literacy ability of students in Indonesia is still low [2]. The low quality of student science learning outcomes shows that the process of learning science in Indonesian schools lacks training in students' scientific literacy. The current trend of learning science is that students learn it as a product, memorizing concepts, theories and laws [3]. The low level of scientific literacy of Indonesian students is a strong evidence that learning science in Indonesia still needs to be improved [4].

Various efforts in earnest to improve this condition, especially the quality of educational services to students. However, the fact that quality of education services as intended is not fully acquired by learners. One important factor which causes the low quality of education and learning is the teacher. Teachers play an important role in the success or failure of a school education. In order for the learning process can take place in school as expected, the professionalism of teachers should be maintained in various ways. Various efforts have been and are being taken by the government to improve the professionalism of teachers. One of the alternative programs that can be made to improve the professionalism of teachers in Indonesia is lesson study [5]. Lesson study is a model of professional development of education through collaborative learning and assessment based on the principles of sustainable collegiality and mutual learning, and to build a learning community.

The lesson study process includes planning, implementing, and evaluating learning. In the planning stage it is necessary to collaborate to produce quality learning materials. One technique that can be used to develop learning materials is through the 4-D model. The 4-D model includes the stages of define, design, develop, and disseminate [6]. This merging of lesson study and 4-D model needs to be applied and therefore this study was conducted.

The ability to think critically is needed in the era of the industrial revolution 4.0. Students who have the ability to think critically are characterized by the ability to think logically, are able to work with ideas, are able to make effective provisions with evidence as evidence of consideration in making logical decisions [7]. Critical thinking is thinking reasoned and reflective by emphasizing decision making about what to believe or do [8]. In order to improve students 'critical thinking 
skills, it is necessary to implement learning strategies that can facilitate the development of students' critical thinking skills. Various studies show that inquiry-based learning strategies can improve students' critical thinking skills. The application of this strategy in learning enables students to develop the ability to observe, measure, collect data, make conclusions [9]. The implementation of this strategy can involve all the abilities possessed by students maximally to search and investigate events or phenomena that exist critically and logically, so that students can formulate their own findings [10]. This study aims to develop valid, practical, and effective inquiry-based science learning materials to improve students' critical thinking skills. The findings of this study serve as evidence to support a viable learning strategy to cultivate critical thinking skills that students need today.

\section{METHODS}

This study consists of 2 (two) stages namely development of inquiry-based learning materials and implementation of the learning materials developed at the first stage. Development of the learning materials refers to the procedure of development model 4-D (four D Models) from [6]. Learning materials developed include: syllabi, lesson plan, student activity sheets, and assessment tools.

The experimental study using a factorial design with two independent variables and one dependent variable. The population were all eighth grade students in 23 junior high schools in Mataram City, Province of West Nusa Tenggara. The number of total sample of 200 students. Students with different academic level are not separated during the study, but the data analysis is separated between the upper and lower academic ability. The data collection used learning observation sheets, and test students' critical thinking skills. The data were analyzed using descriptive and inferential statistics. Descriptive analysis is used to describe the profile of students' critical thinking skills. Meanwhile inferential analysis using Anacova is needed to test the hypothesis.

\section{RESULTS AND DISCUSSION}

The lesson study integration was carried out at the third stage of the 4D model, which is at the develop stage. After obtaining a feasible and practical learning materials for use then an experimental study was carried out. Data from the results of experimental studies are presented in Table 1.

TABLE I. AvERAGE SCORE OF STUDENTS`CRITICAL THINKING SKILls BEFORE AND AFTER LESSONS

\begin{tabular}{|l|l|c|l|l|l|}
\hline No & \multicolumn{1}{|c|}{ Variables } & $\begin{array}{c}\text { Pre- } \\
\text { Tests }\end{array}$ & Category & $\begin{array}{c}\text { Post- } \\
\text { Test }\end{array}$ & $\begin{array}{c}\text { Categor } \\
\mathbf{y}\end{array}$ \\
\hline 1 & Inquiry level 1 & 44.65 & Moderate & 67.01 & Good \\
\hline 2 & Inquiry level 2 & 47.05 & Moderate & 69.47 & Good \\
\hline 3 & Inquiry level 3 & 49.46 & Moderate & 72.68 & Good \\
\hline 4 & Conventional & 43.07 & Moderate & 55.49 & Moderate \\
\hline 5 & Academic above & 48.16 & Moderate & 71.19 & Good \\
\hline 6 & Academic down & 43.95 & Moderate & 61.13 & Good \\
\hline 7 & Academic inquiry on level 1 $*$ & 48.08 & Moderate & 72.36 & Good \\
\hline 8 & Academic inquiry on level 2 $*$ & 50.38 & Moderate & 76.79 & Good \\
\hline 9 & Academic inquiry above level 3* & 50.89 & Moderate & 78.73 & Good \\
\hline 10 & Conventional * Academic above & 43.29 & Moderate & 56.88 & Moderate \\
\hline
\end{tabular}

Table 1. Cont.

\begin{tabular}{|l|l|l|l|l|l|}
\hline 11 & Academic inquiry below level $1 *$ & 41.23 & Moderate & 61.67 & Good \\
\hline 12 & Academic inquiry below level $2 *$ & 43.72 & Moderate & 62.14 & Good \\
\hline 13 & $\begin{array}{l}\text { Level 3 * Academic inquiry } \\
\text { under }\end{array}$ & 47.99 & Moderate & 66.62 & Good \\
\hline 14 & Conventional * Academic down & 42.85 & Moderate & 54.10 & Moderate \\
\hline
\end{tabular}

A summary of the Anacova test results overall effect of learning strategies and academic skills as well as the interaction between the two variables on students' critical thinking skills is presented in Table 2.

TABLE II. SUMMARY OF ANACOVA TEST RESUlTS

\begin{tabular}{|l|l|l|l|l|}
\hline \multicolumn{1}{|c|}{ Source } & $\begin{array}{c}\text { Number of } \\
\text { Squares }\end{array}$ & db & \multicolumn{1}{|c|}{ F } & p (Sig.) \\
\hline $\begin{array}{l}\text { Covariate (initial tests of } \\
\text { critical thinking skills) }\end{array}$ & 644.605 & 1 & 18.691 & 0.000 \\
\hline Learning strategies & 6139.873 & 3 & 59.344 & 0.000 \\
\hline Academic ability & 3469.507 & 1 & 100.603 & 0.000 \\
\hline $\begin{array}{l}\text { Interaction strategies and } \\
\text { academic skills }\end{array}$ & 721.238 & 3 & 6.971 & 0.000 \\
\hline
\end{tabular}

Based on the Anacova test results, an LSD test was performed to determine the differences in average scores at each level of learning strategies. The LSD test results summary is presented in Table 3.

TABLE III. LSD TEST RESULTS SUMMARY

\begin{tabular}{|l|c|c|l|l|c|}
\hline \multicolumn{1}{|c|}{ Strategy } & $\begin{array}{c}\text { Pre- } \\
\text { Tests }\end{array}$ & $\begin{array}{c}\text { Post- } \\
\text { Test }\end{array}$ & Difference & Correction & Notation \\
\hline Conventional & 43.11 & 55.49 & 12.38 & 56.37 & $\mathrm{a}$ \\
\hline Inquiry level 1 & 44.65 & 67.01 & 22.36 & 67.43 & $\mathrm{~b}$ \\
\hline Inquiry level 2 & 47.05 & 69.47 & 22.42 & 69.17 & $\mathrm{~b}$ \\
\hline Inquiry level 3 & 49.45 & 72.68 & 23.23 & 71.67 & $\mathrm{c}$ \\
\hline
\end{tabular}

The results of this study showed that all levels of inquiry describe better results than controls in improving students' critical thinking skills. The characteristics of the inquiry learning is a demand for students to be able to: (1) define the problem, (2) formulate a hypothesis, (3) test the tentative answer, (4) draw conclusions, and (5) implementing the conclusions and generalization. Related to the above, this claim implies logical thinking ability of students were trained [11].

The empowerment of students' critical thinking skills can be done by applying constructivist-oriented teaching strategies, among others, is a strategy of inquiry [12]. According to Rankin [13] that in order to conduct an inquiry in the classroom requires the laying of the foundation so that students become more responsible for their learning. Students become more accustomed to using science process skills (such as observing, questioning, predicting, hypothesizing) to make a decision what questions are asked, what tools and materials needed to complete various tasks, how to organize data, communicate findings and participate in the discussion. Overall activity is directly or indirectly will train the students to think from time to time. 
Inquiry strategy implementation level 3 proved to be more effective to improve students' critical thinking skills compared to the other levels of inquiry strategy implementation (level 1 and level 2). Stages of learning various levels of inquiry in principle have somethings in common, but there are fundamental differences between a level one with the other levels. Syntax inquiry learning level 3 give wider opportunities for students to undertake an inquiry, so that the different stages is at identifying problems, designing experiments and test the hypothesis that students are more dominant. In the inquiry strategy implementation level 3, teachers act more as a facilitator and motivator. Students are conditioned to self-start from the identification and determination of the scope of the problem, formulating hypotheses, designing experiments, data collection, data interpretation and development of conclusions.

The results are consistent with findings reported by Zubaidah [14] who conducted research on Islamic Elementary School fifth grade students, although researchers felt not meet expectations because the time is very limited research. Further explained that the change of critical thinking skills cannot be done in a short time, but it must be done continuously and with a more mature design.

The difference in the students 'academic abilities apparently significant effect on students' critical thinking skills. Based on the results of LSD test, it is known that the average score of critical thinking skills on academic ability students significantly different from the average score of critical thinking skills of students with lower academic. The average score on the critical thinking skills of students with academic over $14.28 \%$ higher than the average score on the critical thinking skills of students with lower academic.

The results of this study support the theory that students with different levels of academic ability if given the same learning, the learning outcomes will be different. These results are also in accordance with results of previous studies conducted by Tindangen [15] which states that if students are capable of academic upper and lower academic ability students be treated the same learning, the ability to think critically differ according to the level of academic ability. Research conducted by the researchers concluded that students are capable of academic upper acquire critical thinking skills higher than students under academic capability.

\section{CONCLUSIONS}

To obtain higher quality learning materials, it can be done by integrating lesson study into the 4-D model development procedure. The integration of lesson study can be done in the third stage of the 4-D model. The learning materials that are already feasible, practical and implemented by teachers who have been trained through the lesson study process provide maximum results in improving student learning outcomes. Inquiry based learning is proven to improve students' critical thinking skills.

\section{REFERENCES}

[1] P. Nuangchalerm, Inquiry-based Learning in China: Lesson learned for School Science Practices. Asian Social Science, vol. 10 no. 13, 2014.

[2] OECD. PISA 2015 Result in Focus. (online) http://www.oecd.org/pisa/pisa-2015-results-in-focus.pdf, Accessed 20 Agustus 2018.

[3] W. Fitriani and I. Lestari, Deskripsi Literasi Sains Siswa Model Inkuiri pada Materi Laju Reaksi di SMAN 9 Pontianak. Jurnal Pendidikan dan Pembelajaran, vol. 3 no 1, 2014

[4] W. Widodo, M.I.S. Putra, and B. Jatmiko, The Development of Guided Inquiry Science Learning Materials to Improve Science Literacy Skill of Prospective MI Teachers. Jurnal Pendidikan IPA Indonesia, vol. 5 no 1, 2016.

[5] I. Syamsuri and Ibrohim. Lesson Study (Studi Pembelajaran). Malang: Penerbit Universitas Negeri Malang. 2011.

[6] S. Thiagarajan, D.S. Semmel, and M.I. Semmel, Instructional Development for Training Teachers of Exceptional Children. Bloomington: Center for Innovation in Teaching the Handicapped. 1974.

[7] M. Asyari, M.H.I. Al Muhdhar, H. Susilo, Ibrohim. "Improving Critical Thinking Skills through the Integration of Problem Based Learning and Group Investigation,” International Journal for Lesson and Learning Studies, vol. 5 no. 1, 2016.

[8] Suhartatik. Pengembangan Modul IPA SMP Berbasis Guided Discovery untuk Meningkatkan Kemampuan Berpikir Kritis dan Hasil Belajar Kognitif Siswa. Proseding Seminar Pendidikan, Pascasarjana UM. vol 1, 2016.

[9] K. Saglam, Inquiry-based Professional Development Practice for Science Teacher. Turkish Science Education Journal. vol 4, 2017.

[10] S. Amijaya, A. Ramdani, I.W. Merta, Pengaruh Model Pembelajaran Inkuiri Terbimbing terhadap Hasil Belajar dan Keterampilan Berpikir Kritis Peserta Didik. Jurnal Pijar MIPA, vol 13, 2018.

[11] S.K. Wah Cu, S.K. Tse, K. Chow, Using Collaborative Teaching and Inquiry Project-based Learning to help Primary School Students Develop Information Literacy and Information Skill. Library \& Information Science Research, vol 33, 2011.

[12] K. Changwong, A. Sukkamart, Sisan. Critical Thinking Skill Development: Analysis of a new learning management model for Thai high schools. Journal of International Studies, vol 11 no 2, 2018.

[13] L. Rankin, Pathways to Inquiry. Science \& Children, vol 48, 2011.

[14] S. Zubaidah, Pembelajaran Kontekstual dengan Metode Inkuiri untuk Meningkatkan Kemampuan Berpikir dan Motivasi Belajar IPA Siswa Kelas V Madrasah Ibtidaiyah Wahid Hasyim III Malang. Jurnal Pendidikan dan Pembelajaran. vol 15 no 1, 2008.

[15] M. Tindangen, Implementasi Pembelajaran Kontekstual Peta Konsep Biologi SMP pada Siswa Berkemampuan Awal Berbeda di Kota Malang dan Pengaruhnya terhadap Kemampuan Berpikir Tingkat Tinggi dan Kemampuan Berpikir Kritis. Disertasi Universitas Negeri Malang. 2006. 